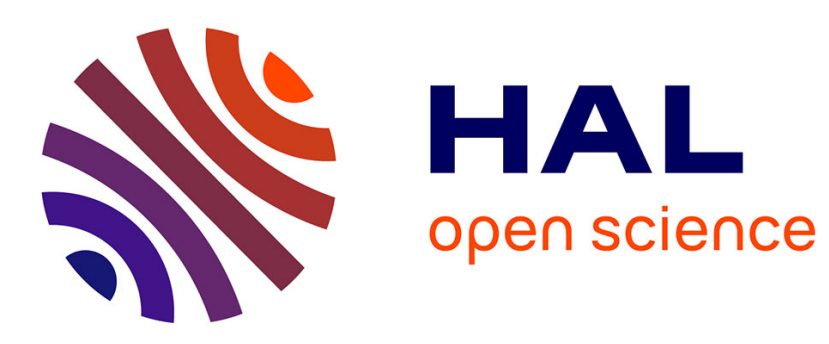

\title{
Iron Porphyrin Allows Fast and Selective Electrocatalytic Conversion of CO 2 to $\mathrm{CO}$ in a Flow Cell
}

Niklas von Wolff, Kristian Torbensen, Cheng Han, Benjamin Boudy, Caroline Bertail, Waldemar Braun, Marc Robert

\section{To cite this version:}

Niklas von Wolff, Kristian Torbensen, Cheng Han, Benjamin Boudy, Caroline Bertail, et al.. Iron Porphyrin Allows Fast and Selective Electrocatalytic Conversion of CO 2 to $\mathrm{CO}$ in a Flow Cell. Chemistry - A European Journal, 2020, 26 (14), pp.3034-3038. 10.1002/chem.202000160 . hal03008799

\section{HAL Id: hal-03008799 \\ https://hal.science/hal-03008799}

Submitted on 21 Jun 2021

HAL is a multi-disciplinary open access archive for the deposit and dissemination of scientific research documents, whether they are published or not. The documents may come from teaching and research institutions in France or abroad, or from public or private research centers.
L'archive ouverte pluridisciplinaire HAL, est destinée au dépôt et à la diffusion de documents scientifiques de niveau recherche, publiés ou non, émanant des établissements d'enseignement et de recherche français ou étrangers, des laboratoires publics ou privés. 


\title{
Iron Porphyrin Does Fast and Selective Electrocatalytic Conversion of $\mathrm{CO} 2$ to $\mathrm{CO}$ in a Flow Cell
}

\author{
Kristian Torbensen, ${ }^{[a]}$ Cheng Han, ${ }^{[a],[b]}$ Benjamin Boudy, ${ }^{[a]}$ Niklas von Wolff, ${ }^{[a]}$ Caroline Bertail, ${ }^{[c]}$ Waldemar Braun ${ }^{[d]}$ and Marc \\ Robert ${ }^{*[a]}$ \\ [a] Dr., K., Torbensen, Dr., C., Han, Mr. B., Boudy, Dr., N., von Wolff,Prof., Dr. M., Robert \\ Université de Paris, Laboratoire d'Electrochimie Moléculaire, CNRS,F-75013 Paris, France \\ E-mail: robert@univ-paris-diderot.fr \\ [b] Dr., C., Han \\ College of Aerospace Science and Engineering, National University of Defense Technology, 109 Deya Road, Changsha, Hunan 410073, \\ P. R. China \\ [c] Dr. C., Bertail, \\ Air Liquide Research\&Development Paris Innovation Campus, F-78354 Jouy en Josas, France \\ [d] Dr. W., Braun \\ Air Liquide Forschung und Entwicklung GmbH, Gwinnerstraße 27-33, 60388 Frankfurt, Germany
}

Supporting information for this article is given via a link at the end ofthe document.

\begin{abstract}
Molecular catalysts have been shown to have high selectivity for $\mathrm{CO}_{2}$ electrochemical reduction to $\mathrm{CO}$, but with current densities significantly below those obtained with solid-state materials. By depositing a simple Fe porphyrin mixed with carbon black onto a carbon paper support, we have obtained a catalytic material that could be used in a flow cell for fast and selective conversion of $\mathrm{CO}_{2}$ to $\mathrm{CO}$. At neutral $\mathrm{pH}$ (7.3) a current density as high as $83.7 \mathrm{~mA} \mathrm{~cm}^{-2}$ was obtained with a CO selectivity close to $98 \%$. In basic solution $(\mathrm{pH} 14)$, a current density of $27 \mathrm{~mA} \mathrm{~cm}{ }^{-2}$ was maintained for $24 \mathrm{~h}$ with $99.7 \%$ selectivity for $\mathrm{CO}$ at only $50 \mathrm{mV}$ overpotential, leading to a record energy efficiency of $71 \%$. In addition, a current density for $\mathrm{CO}$ production as high as $152 \mathrm{~mA} \mathrm{~cm}^{-2}$ (>98\% selectivity) was obtained at a low overpotential of $470 \mathrm{mV}$, outperforming state-of-the-art noble metal based catalysts.
\end{abstract}

$\mathrm{CO}_{2}$ may be used as renewable feedstock for producing fuels or commodity chemicals with renewable electricity as energy source. ${ }^{[1-2]}$ However, selective, robust and fast electrochemically driven conversion of $\mathrm{CO}_{2}$ remains a great challenge in the scientific field and as well as in the industrial environment. Therefore, new approaches are needed to develop electrolyzers operating at industrial relevant scales while fulfilling customer needs and requirements. Regarding the catalysts employed, molecular complexes have been widely investigated for the carbon dioxide reduction reaction $\left(\mathrm{CO}_{2} \mathrm{RR}\right)$ due to the possibility of fine tuning the ligand structure (steric and electronic effects, aswell as second coordination sphere effects). ${ }^{[3-6]}$ Earth abundant metal-based catalysts have been shown to efficiently catalyze theproduction of $\mathrm{CO}$ and formate in organic solvents and in water, ${ }^{[7-11]}$ even if examples in pure aqueous solutions are less numerous. In the latter case, the catalysts are typically dispersed into thin conductive films usually made of carbon nanomaterials, such as carbon black or carbon nanotubes. ${ }^{[12-20]}$ Until very recently, these molecular catalysts were deemed to be incapable to operate in flow cells at both high product selectivity and conversion rate. Using Co phthalocyanine as catalysts, we have shown that this dogma can be overcome by applying the complex into a flow cell, generating $\mathrm{CO}$ with $94 \%$ selectivity at $165 \mathrm{~mA} / \mathrm{cm}^{2}$ current densityat basic $\mathrm{pH}$ (14). ${ }^{[21-22]}$ Such performances approach those obtained with $\mathrm{Ag}$ and $\mathrm{Au}$ based catalytic materials. ${ }^{[23-25]}$ However, the Co complex, like the above mentioned solid nano- catalysts, operates at quite large overpotential, in the range of $800 \mathrm{mV}$ at comparably current densities. The selectivity could also be still improved, while the exclusive use of earth abundant elements instead of expensive metals is mandatory. In this context, $\mathrm{Fe}$ is an ideal candidate being the most abundant transition metal. As previously shown, tetraphenyl Fe porphyrin substituted with trimethyl ammonium groups at the para position of each of the four phenyl groups (FeP, Scheme 1 (left), ${ }^{[26-27]}$ is able to produce $\mathrm{CO}$ with a selectivity of $90 \%$ at neutral $\mathrm{pH}$ and at an overpotential of $450 \mathrm{mV}$. However, maximum current density obtained in an $\mathrm{H}$-cell device was in the range of $1 \mathrm{~mA} \mathrm{~cm}^{-2}$. $^{[27]}$ Using FeP/grapheneframework ${ }^{[28]}$ or FeP/graphene hydrogel[29] assemblies also led to high selectivity for $\mathrm{CO}(96-98.7 \%)$ and a maximum current densityof about $1.7 \mathrm{~mA} \mathrm{~cm}^{-2}$ at ca. $430 \mathrm{mV}$ overpotential was shown. Supramolecular porous structures made of $\mathrm{Fe}$ tetraphenylporphyrin units have also been used as catalysts. ${ }^{[30-}$ ${ }^{31]}$ After deposition at the surface of a carbon electrode, it led to goodselectivity for $\mathrm{CO}$ production (ca. 90\%), with a current density of $1.2 \mathrm{~mA} \mathrm{~cm}^{-2}$ at $\sim 500 \mathrm{mV}$ overpotential. With these encouraging preliminary results at hand, and keeping in mind the idea of a simple, cheap and easy-to-prepare material, we manufactured gas diffusion electrodes by depositing a thin nanoscaled film containing FeP and carbon particles onto a carbon paper support. When implemented in an electrolyzer, this catalytic material proved to be exceptionally active for the $\mathrm{CO}_{2} \mathrm{RR}$, even surpassingthe performance of noble metal based nanomaterials
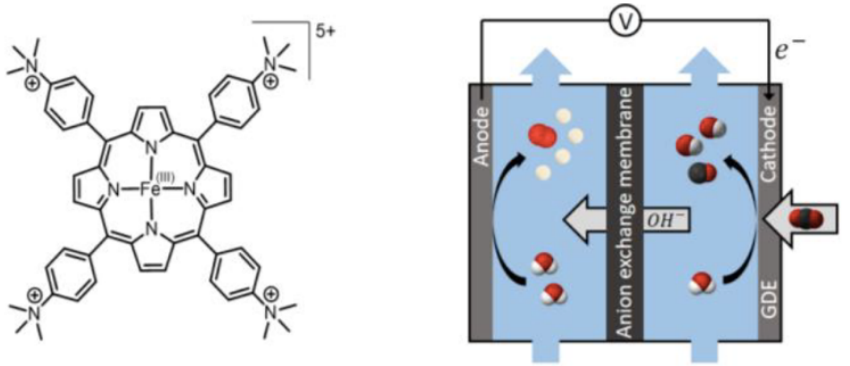

Scheme 1. Structure of the catalyst FeP (left, counterions omitted for clarity) and schematic view of the flow cell operating in $\mathrm{pH}$ neutral conditions (right). 
The catalytic ink was prepared from a suspension of carbon black and FeP. It allows to ensure good electronic conduction between the molecular catalyst and the support. The ink was deposited onto carbon paper by drop casting, leading to a $1 \mathrm{~cm} 2$ gas diffusion electrode (GDE), with a FeP loading of $2.08 \mathrm{mg} \mathrm{cm}-2$. SEM images of the film are shown in Figure S1. Qualitative EDX elemental mapping analysis was performed and a homogeneous distribution of the catalyst at the GDE (Figure S2) was found. We then verified that immobilization of the catalyst did not alter its molecular integrity. Fe K-edge X-Ray absorption near-edge structure spectra recorded at a FeP loaded GDE and from a FeP pellet did not show any significant difference (Figure S3A), while UV-vis spectra of FeP was similar to the spectra obtained after extracting the complex from a GDE using DMF as solvent (Figure S3B). Cyclic voltammetry was also performed at a GDE to verify that the FeP was electrochemically active. However, due to the hydrophobic nature of the film, only a small fraction of the total amount of catalyst could be addressed when interrogated from the front side of the GDE (see Figure S4 for further explanation). Upon introducing $\mathrm{CO}_{2}$ to the electrochemical cell, a clear catalytic response was observed (Figure S5). The catalyst coated GDE was then inserted into a flow cell setup, Scheme 1 (right). The electrolyzer consists of a sandwich of mounted flow frames, electrodes, gaskets and an ion exchange membrane, which were assembled as schematically illustrated in Figure $\mathrm{S} 6 . \mathrm{CO}_{2}$ is allowed to flow through the gas diffusion electrode, while the catholyte solution is circulated in between the GDE and the anion exchange membrane (AEM). Within the GDE, $\mathrm{CO}_{2}$ undergoes a 2-electron-2-proton reduction forming $\mathrm{CO}$ and $\mathrm{OH}^{-}$. In the anodic compartment, water is oxidized to dioxygen and $\mathrm{H}^{+}$at a Pt/Ti alloy electrode. The AEM allows for diffusion of $\mathrm{OH}^{-}$, thereby maintaining overall electroneutrality upon reacting with protons. In the following electrolysis experiments, no liquid $\mathrm{CO}_{2}$ reduction products could be detected by NMR or ion chromatography.

Catalytic activity was first investigated as a function of the applied potential in a $\mathrm{CO}_{2}$-saturated $0.5 \mathrm{M} \mathrm{NaHCO}_{3}$ solution. Figure 1 illustrates the current density increase as a function of the potential, along with the selectivity for CO production (see alsoTable S1). At a low overpotential ( ) of $270 \mathrm{mV}$ (no IR drop correction was applied throughout the paper), $\mathrm{CO}$ was detected as the only product $(99.9 \%$ selectivity) with a total current densityof $7.2 \mathrm{~mA} \mathrm{~cm}^{-2}$.

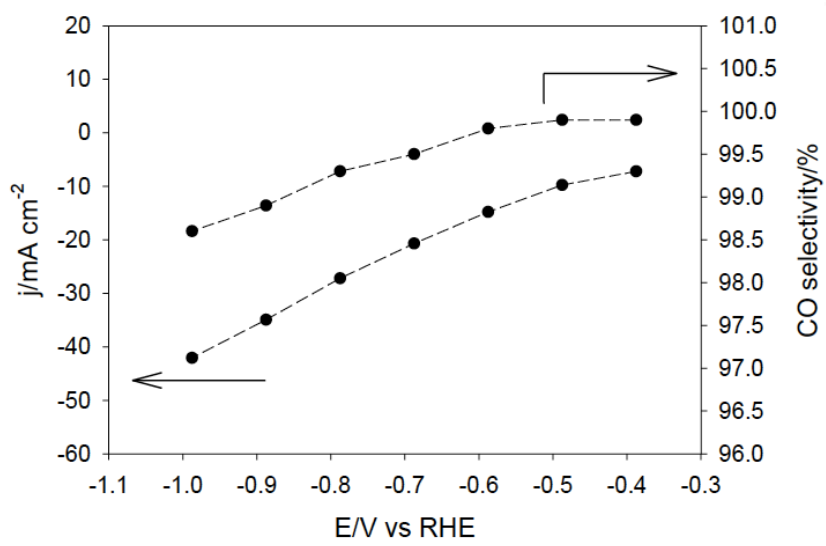

Figure 1. Current density (left axis) at the gas diffusion electrode and $\mathrm{CO}$ selectivity (right axis) as a function of the applied potential in $0.5 \mathrm{M} \mathrm{NaHCO}_{3}$ electrolyte solution.
Selectivity for carbon monoxide remained above or equal to $99 \%$ up to $700 \mathrm{mV}$ overpotential, and $\mathrm{H}_{2}$ was the only minor by-product that could be detected. At a potential of $-0.98 \mathrm{Vvs}$. $\mathrm{RHE}$, the current density reached $42.1 \mathrm{~mA} \mathrm{~cm}{ }^{-2}$ along with $98.6 \%$ CO selectivity. The catalyst ability to suppress the $\mathrm{H}_{2}$ evolution reaction (HER) in favor of the $\mathrm{CO}_{2} \mathrm{RR}$ was further verified by inserting in the electrolyzer a carbon film with nonmetalated porphyrin, which resulted in exclusive $\mathrm{H}_{2}$ production (Figure S7).

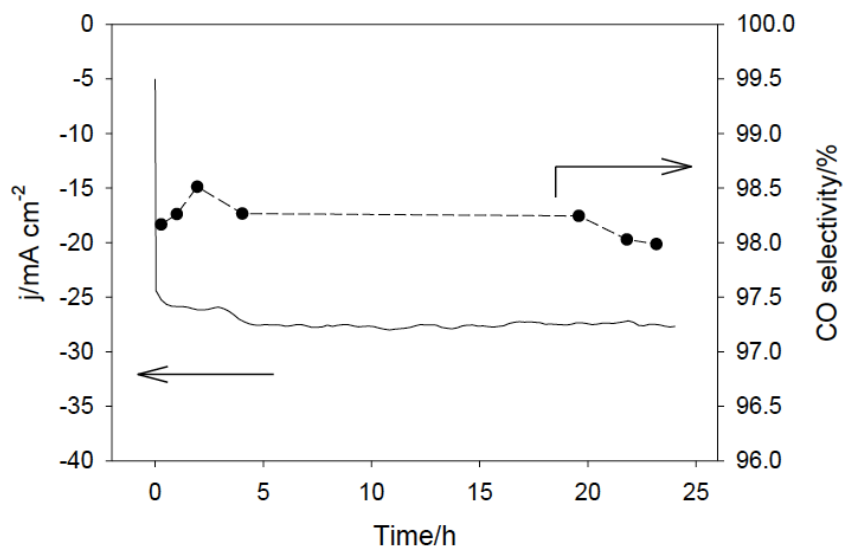

Figure 2. Current density (left axis) and CO selectivity (right axis) during a $24 \mathrm{~h}$ electrolysis at $E=-0.78 \mathrm{~V}$ vs $\mathrm{RHE}$ in $0.5 \mathrm{M} \mathrm{NaHCO}_{3}$ electrolyte solution.

Encouraged by these results, a high current density of $50 \mathrm{~mA} \mathrm{~cm}$ ${ }^{2}$ could be sustained for about 3 hours at a potential of $-1.14 \mathrm{~V}$ vs $\operatorname{RHE}(\eta=1.03 \mathrm{~V})$, with $98.3 \pm 0.3 \%$ average selectivity and a production of $0.9 \mathrm{mmol} \mathrm{h}_{-1} \mathrm{CO}$ (Figure S10). This was obtained at the expense of an increase of the cell potential $(4.05 \mathrm{~V})$, lowering the EE to $33 \%$. The Ohmic resistance of the electrolyzer cell could be reduced upon increasing the electrolyte concentration. Using a $1.0 \mathrm{M} \mathrm{NaHCO}_{3}$ electrolyte solution, a current density of $50 \mathrm{~mA}$ $\mathrm{cm}^{-2}$ was sustained for $3 \mathrm{~h}$ at only $-0.86 \mathrm{~V}$ vs RHE $(\eta=0.75 \mathrm{~V})$, reducing the cell potential by $590 \mathrm{mV}$ and increasing the energy efficiency up to $38 \%$ (Figure S11). The CO product selectivity was maintained at a high value of $99.0 \pm 0.2 \%$ on average. Increasing the temperature from $24{ }^{\circ} \mathrm{C}$ up to $40{ }^{\circ} \mathrm{C}$ led to larger current densities, as shown in Figure 3, while maintaining a high $\mathrm{CO}$ selectivity. At $E=-0.78 \mathrm{~V}$ vs RHE, the current density raised from 28 to $39 \mathrm{~mA} \mathrm{~cm}^{-2}$ (in $0.5 \mathrm{M} \mathrm{NaHCO}_{3}$ ). It was verified that the $\mathrm{pH}$ of the electrolyte solution was about constant within this temperature range. Regarding thermodynamics, increasing the temperature amounts to decreasing the overpotential since the apparent standard potential for converting $\mathrm{CO}_{2}$ into $\mathrm{CO}$ is $E_{0}-(\mathrm{RT} \ln 10 / 2 \mathrm{~F})$ $\mathrm{x} \mathrm{pH}$. Thus, the observed rate increase could be attributed to enhanced kinetics.

As recently demonstrated, ${ }^{[32]}$ the GDE likely counterbalances $\mathrm{CO}_{2}$ solubility decrease when $T$ is raised, preventing catalysis limitation by mass transport and ensuring a constant (steady state) $\mathrm{CO}_{2}$ concentration at the catalytic sites. TOF values are hence equivalent to pseudo first order rate constant for the $\mathrm{CO}$ production. An Eyring plot provided an activation enthalpy of $9.5 \mathrm{~kJ} \mathrm{~mol}-1$ and an activation entropy of -231 Jmol-1 K-1, suggesting an associative rate determining step, possibly $\mathrm{CO}_{2}$ binding to the reduced $\mathbf{F e P}$, as already proposed from electrochemical studies (Figure S12). A prolonged electrolysis was performed for $3 \mathrm{~h}$ at a constant current density of $50 \mathrm{~mA} \mathrm{~cm}$ - 
2 (in $0.5 \mathrm{M} \mathrm{NaHCO}_{3}$ ) at $40^{\circ} \mathrm{C}$ (Figure S13), leading to $98.6 \pm 0.1 \%$ selectivity for $\mathrm{CO}$ at an average overpotential of just $730 \mathrm{mV}$ (compared to $1.03 \mathrm{~V}$ at $24^{\circ} \mathrm{C}$ ), illustrating the positive impact of such small temperature increase.

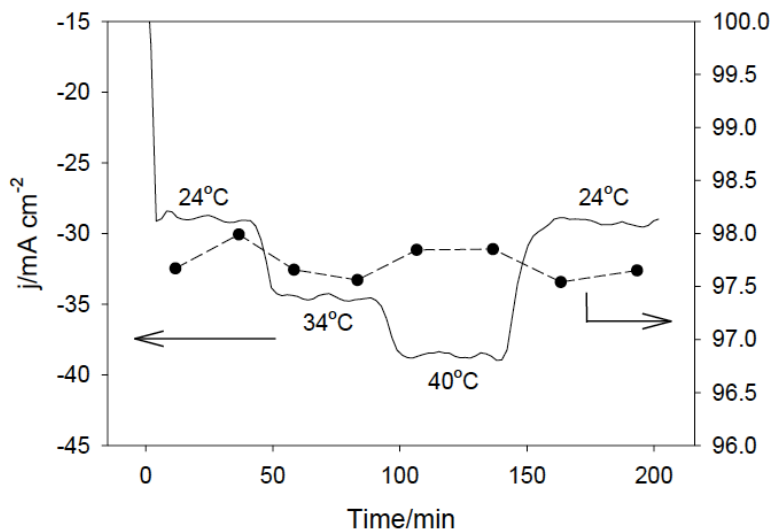

Figure 3. Current density (left axis) and $\mathrm{CO}$ selectivity (right axis) obtained at various temperatures as indicated. Electrolysis performed at $E=-0.78 \mathrm{~V}$ vs $\mathrm{RHE}$ in $0.5 \mathrm{M} \mathrm{NaHCO}_{3}$ electrolyte solution.

Besides increasing the electrolyte salt concentration and temperature, it was recently shown that the cation size of the electrolyte may also impact the catalytic performance. ${ }^{[33-34]}$ Using a $0.5 \mathrm{M} \mathrm{CsHCO}_{3}$ as electrolyte solution (see Figure $\mathrm{S} 14$ and Table S2), a significant performance increase was obtained with a current density of $9 \mathrm{~mA} \mathrm{~cm}{ }^{-2}$ at $270 \mathrm{mV}$ overpotential $(99.9 \%$ CO selectivity) and a current density (at $\eta=870$ ) of $83.7 \mathrm{~mA} \mathrm{~cm}$ 2 (97.6\% selectivity), a value two times larger than the one obtained using a $0.5 \mathrm{M} \mathrm{NaHCO}_{3}$ solution. Comparative electrolysis at $50 \mathrm{~mA} \mathrm{~cm}{ }^{-2}$ (Figure S15) led to a $390 \mathrm{mV}$ overpotential decrease along with a slight $\mathrm{CO}$ selectivity increase and an EE gain of $8 \%$, as summarized in Table 1.

Table 1. Catalytic performances for $3 \mathrm{~h}$ electrolysis at $50 \mathrm{~mA} \mathrm{~cm}^{-2}$ in a $0.5 \mathrm{M}$ electrolyte solution $\left(\mathrm{NaHCO}_{3}, \mathrm{KHCO}_{3}\right.$ or $\left.\mathrm{CsHCO}_{3}\right)$.

\begin{tabular}{|c|c|c|c|c|}
\hline Cation & E/V vs RHE & $\eta / V$ & $\begin{array}{l}\text { CO } \\
\text { Selectivity } / \%\end{array}$ & $\mathrm{EE} / \%$ \\
\hline $\mathrm{Na}+$ & -1.14 & 1.03 & 98.3 & 33 \\
\hline $\mathrm{K}+*$ & -0.95 & 0.84 & 98.6 & 36 \\
\hline Cs+ & -0.75 & 0.64 & 98.9 & 41 \\
\hline
\end{tabular}

*Electrolysis in $0.5 \mathrm{M} \mathrm{KHCO}_{3}$ electrolyte (Figure $\mathrm{S} 16$ ) was performed so as toconfirm the trend described in the text.

As recently suggested by Chan et al., ${ }^{[34]}$ cations having the smallest hydration radius, which is inversely proportional to the ionic radius, may lead to the strongest interfacial electric field, favoring $\mathrm{CO}_{2}$ adsorption at catalytic sites. Alkaline conditions allowed to boost the performance a step further. Using $1 \mathrm{M} \mathrm{KOH}$ as electrolyte, a current density of $37.6 \mathrm{~mA} \mathrm{~cm}^{-2}$ was obtained at $70 \mathrm{mV}$ overpotential with perfect selectivity for CO (99.9\%). A current density of $155 \mathrm{~m} \mathrm{Acm}^{-2}$ was reached at $\eta=470 \mathrm{mV}$ with a selectivity for CO of $98.1 \%$, corresponding to a partial current density for $\mathrm{CO}(\mathrm{jco})$ of $152 \mathrm{~mA} \mathrm{~cm}^{-2}$ (see Figure 4 and Table S3).
Such current density for $\mathrm{CO}$ production is significantly higher than that obtained with a state-of-the art noble metal based material (500 nm thick Ag film mixed with carbon particles and deposited at a PTFE membrane) which gave a jco of ca. $90 \mathrm{~mA} \mathrm{~cm}^{-2}$ at $\eta \sim 480 \mathrm{mV} .{ }^{[24]}$ Figure 4 display the current density increase as a function of the potential, along with the selectivity for $\mathrm{CO}$ production (see also Table S3). A control experiment with the nonmetalated porphyrin ligand only afforded $\mathrm{H} 2$ as reduction product (Figure S17).

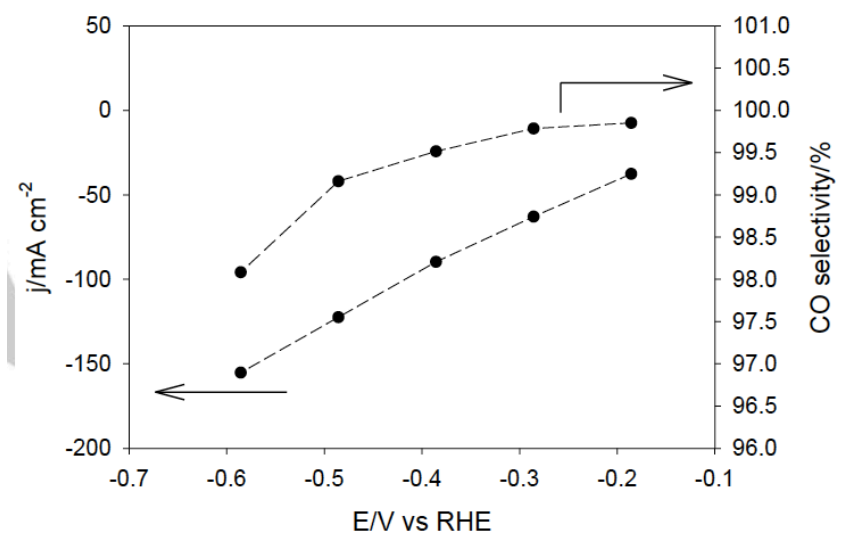

Figure 4. Current density (left axis) at the gas diffusion electrode and $\mathrm{CO}$ selectivity (right axis) as a function of the applied potential in $1 \mathrm{M} \mathrm{KOH}$ electrolyte solution.

To compare the endurance of FeP in similar conditions with the pervious results gathered at $\mathrm{pH}$ close to neutral, a chronopotentiometric electrolysis was performed at $27 \mathrm{~mA} \mathrm{~cm}{ }^{-2}$ for $24 \mathrm{~h}$. As shown in Figure 5, an average potential of $-0.16 \mathrm{~V}$ vs RHE $(\eta=0.05 \mathrm{~V})$ was measured, showing only a minute increase over time.

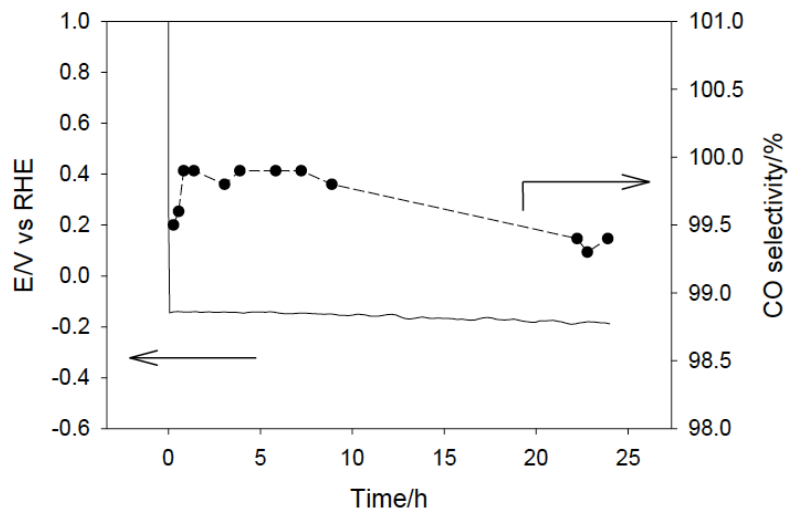

Figure 5. Applied potential (left axis) and CO selectivity (right axis) for a $24 \mathrm{~h}$ electrolysis performed at $27 \mathrm{~mA} \mathrm{~cm}^{-2}$ in $1 \mathrm{M} \mathrm{KOH}$ electrolyte solution.

The CO product selectivity was $99.7 \pm 0.2 \%$ on average with a total CO production of $0.5 \mathrm{mmol} \mathrm{h}-1$, a TON of 8719 and a TOF of $363 \mathrm{~h}^{-1}$. The cell potential was only $1.87 \mathrm{~V}$, corresponding to an EE of $71 \%$. EDX elemental mapping of the GDE after the $24 \mathrm{~h}$ electrolysis showed that $\mathrm{FeP}$ was still present and homogeneously dispersed in the film (Figure S18). XANES of the 
GDE and UV-vis of catalyst extracted from the GDE after electrolysis further proved the molecular integrity of $\mathrm{FeP}$ intact (Figures S19A and S19B). Finally, at $50 \mathrm{~mA} \mathrm{~cm}^{-2}$ current density, a remarkably low overpotential of $120 \mathrm{mV}$ was maintained during a $3 \mathrm{~h}$ electrolysis, producing $0.9 \mathrm{mmol} \mathrm{h}^{-1} \mathrm{CO}$ with $99.8 \pm 0.2 \%$ selectivity, a TON of 2023 and a TOF of $674 \mathrm{~h}^{-1}$, along with an EE of $57 \%$ (Figure S20).

In conclusion, FeP appears as an exceptionally efficient supported homogeneous catalyst for the conversion of $\mathrm{CO}_{2}$ to $\mathrm{CO}$ in water once inserted in a flow cell. From neutral $\mathrm{pH}$ to alkaline conditions, selectivities larger than $98 \%$ were systematically obtained, thanks to the high reactivity of the catalyst with $\mathrm{CO} 2$ and the low overpotential values that makes the HER pathway unfavorable. The catalytic material proved to be stable under operating conditions over prolonged electrolysis time. Slight increase in temperature (from 25 to $40^{\circ} \mathrm{C}$ ) as well as increasing the electrolyte concentration and the cation size were beneficial to both the $\mathrm{CO}$ production rate, the selectivity of the $\mathrm{CO}_{2}$-to- $\mathrm{CO}$ conversion and the energy efficiency. Remarkably, a very high current density for $\mathrm{CO}$ could be obtained at a low overpotential (jco $>150 \mathrm{~mA} \mathrm{~cm}-2$ at $\eta=470 \mathrm{mV}$ ), outperforming state of the art silver based nanomaterials. These results illustrate that molecular catalysts can be used in flow cell devices and are candidates for being included into large scale $\mathrm{CO} 2$ electrolyzers.

\section{Acknowledgements}

The work described in this project was financed in part by Air Liquide and the Institut Universitaire de France (IUF). PhD fellowship to C. $\mathrm{H}$ from China Scholarship Council (CSC, grant number 201603170259) is gratefully acknowledged. We thank Ms. D. Mendoza and Dr. B. Lassalle-Kaiser for collecting Xray absorption data at SOLEIL synchrotron facilities..

Keywords: carbon dioxide reduction $\cdot$ carbon monoxide $\cdot \mathrm{Fe}$ complex $\bullet$ flow cell• hybrid materials

[1] A. Tatin, J. Bonin, M. Robert, ACS Energy Lett. 2016, 1, 1062-1064.

[2] P. De Luna, C. Hahn, D. Higgins, S. A. Jaffer, T. F. Jaramillo, E. H. Sargent, Science 2019, 364, eaav3506.

[3] H. Takeda, C. Cometto, O. Ishitani, M. Robert, ACS Catal. 2017, 7, 70- 88.

[4] K. A. Grice, Coord. Chem. Rev. 2017, 336, 78-95.

[5] R. Francke, B. Schille, M. Roemelt, Chem. Rev. 2018, 118, 4631-4701.

[6] K. E. Dalle, J. Warnan, J. J. Leung, B. Reuillard, I. S. Karmel, E. Reisner, Chem. Rev. 2019, 119, 2752-2875.

[7] N. D. Loewen, T. V. Neelakantan, L. A. Berben, Acc. Chem. Res. 2017, 50, 2362-2370.

[8] C. Costentin, M. Robert, J-M. Savéant, A. Tatin, Proc. Natl. Acad. Sci. USA 2015, 112, 6882-6886.

[9] I. Azcarate, C. Costentin, M. Robert, J.-M. Savéant, J. Am. Chem. Soc. 2016 138, 16639-16644.

[10] N. D. Loewen, T. V. Neelakantan, L. A. Berben, Acc. Chem. Res. 2017, 50, 2362-2370.

[11] E. A. Mohamed, Z. N. Zahran, Y. Naruta, Chem. Mat. 2017, 29, 7140- 7150

[12] S. Aoi, K. Mase, K. Ohkubo, S. Fukuzumi, Chem. Commun. 2015, 50, 10226-10228

[13] A. Maurin, M. Robert, J. Am. Chem. Soc. 2016, 138, 2492-2495.

[14] X-M. Hu, M. H. Ronne, S. U. Pedersen, T. Skrydstrup, K. Daasbjerg, Angew. Chem. Int. Ed. 2017, 56, 6468-6472.

[15] X. Zhang, Z. Wu, X Zhang et al., Nat. Commun. 2017, 8:14675.
[16] N. Han, Y. Wang, L. Ma et al., Chem 2017, 3, 652-664.

[17] M. Wang, L. Chen, T-C. Lau, M. Robert, Angew. Chem. Int. Ed. 2018, 57, 7769-7773.

[18] J. Choi, P. Wagner, S. Gambir, R. Jalili, D. R. MacFarlane, G. G. Wallace, D. L. Officer, ACS Energy Lett. 2019, 4, 666-672.

[19] M. Zhu, J. Chen, L. Huang, R. Ye, J. Xu, Y-F. Han, Angew. Chem. Int. Ed. 2019, 58, 6595-6599.

[20] L. Rotundo, J. Filippi, R. Rocca, R. Gobetto, H. A. Miller, C. Nervi, F. Vizza, Chem. Commun. 2019, 55, 775-777.

[21] M. Wang, K. Torbensen, D. Salvatore, S. Ren, D. Joulie, F. Dumoulin, D. Mendoza, B. Lassalle-Kaiser, U. Işci, C. Berlinguette, M. Robert, Nat. Commun. 2019, 10:3602.

[22] S. Ren, D. Joulie, D. Salvatore, K. Torbensen, M. Wang, M. Robert, C. Berlinguette, Science 2019, 365, 367-369.

[23] R. B. Kutz, Q. Chen, H. Yang, S. D. Sajjad, Z. Liu, I. R. Masel, Energy Technol. 2017, 5, 929-936.

[24] C-T., Dinh, F. P., García de Arquer, D. Sinton, D., E. H. Sargent, ACS Energy Lett. 2018, 3, 2835-2840.

[25] S. Verma, Y. Hamasaki, C. Kim, W. Huang, S. Lu, S., H-R. M., Jhong, A. A. Gewirth, T. Fujigaya, N. Nakashima, P. J. A. Kenis, ACS Energy Lett. 2018, 3, 193-198.

[26] C. Costentin, M. Robert, J-M. Savéant, A. Tatin, Proc. Natl. Acad. Sci. USA 2015, 112, 6882-6886.

[27] A. Tatin, C. Cominges, B. Kokoh, C. Costentin, M. Robert, J-M. Savéant, Proc. Natl. Acad. Sci. USA 2016, 113, 5526-5529.

[28] J. Choi, P. Wagner, S. Gambir, R. Jalili, J. Kim, D. R. MacFarlane, G. G Wallace, D. L. Officer, Adv. Energy Mater. 2018, 1801280.

[29] J. Choi, J. Kim, P. Wagner, S. Gambir, R. Jalili, S. Byun, S. Sayyar, Y. M. Lee, D. R. MacFarlane, G. G. Wallace, D. L. Officer, Energy Environ. Sci. 2019, 12, 747-755.

[30] P. T. Smith, B. P. Benke, Z. Cao, Y. Kim, E. M. Nichols, K. Kim, C. J. Chang, Angew. Chem. Int. Ed. 2018, 57, 9684-9688.

[31] B-X. Dong, S-L. Qian, F-Y. Bu, Y-C. Wu, L-G. Feng, Y-L. Teng, W-L. Liu, Z-W Li, ACS Appl. Energy Mater. 2018, 1, 4662-4669.

[32] A. Löwe, C. Rieg, T. Hierlemann, N. Salas, D. Kopjlar, N. Wagner, E. Klemm, ChemElectroChem 2019, 6, 4497-4506.

[33] M. M. de Salles Pupo, R. Kortlever, ChemPhysChem, doi.org/10.1002/cphc.201900680.

[34] S. Ringe, E. L. Clark, J. Resasco, A. Walton, B. Seger, A. T. Bell, K. Chan, Energy Environ. Sci. 2019,12, 3001-3014. 


\section{Entry for the Table of Contents}

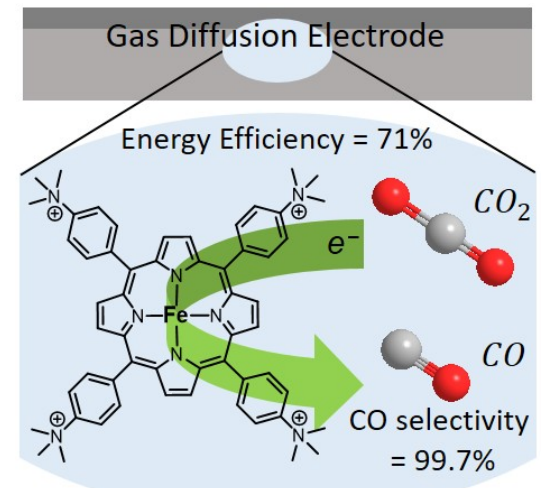

Kristian Torbensen, Cheng Han, Benjamin Boudy, Niklas von Wolff, Caroline Bertail, Waldemar Braun andMarc Robert*

Page No. - Page No.

Iron Porphyrin Does Fast and Selective Electrocatalytic Conversionof $\mathrm{CO}_{2}$ to $\mathrm{CO}$ in a Flow Cell 